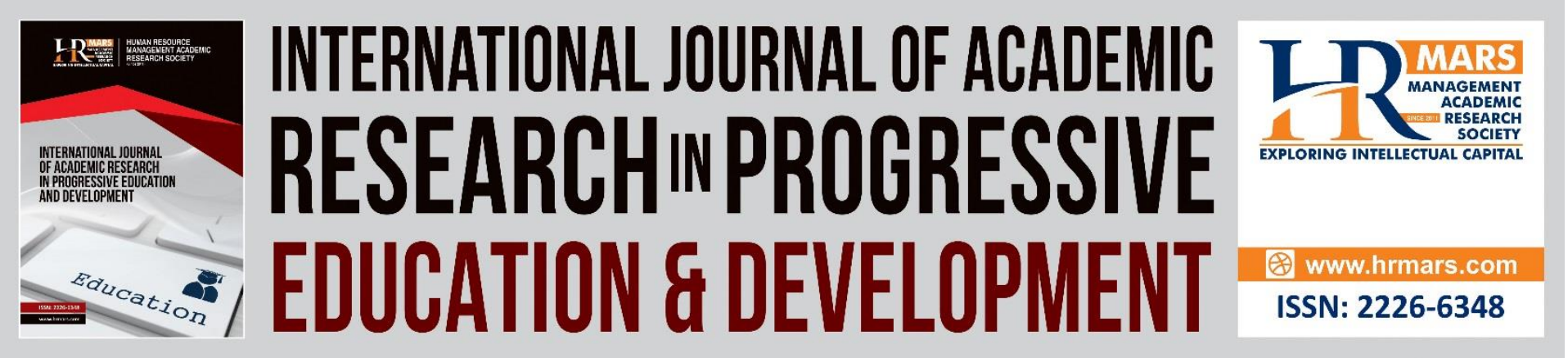

\title{
Parents' Perceptions of Multiprofessional Collaboration during Their Children's with Special Needs Transition to School in Finland
}

Katri Piippo-Naatanen, Satu Uusiautti, Kaarina Maatta

To Link this Article: http://dx.doi.org/10.6007/IJARPED/v1-i4/11966

DOI: $10.6007 /$ IJARPED/v1-i4/11966

Received: 11 September 2012, Revised: 13 October 2012, Accepted: 19 October 2012

Published Online: 21 November 2012

In-Text Citation: (Piippo-Naatanen et al., 2012)

To Cite this Article: Piippo-Naatanen, K., Uusiautti, S., \& Maatta, K. (2012). Parents' Perceptions of Multiprofessional Collaboration during Their Children's with Special Needs Transition to School in Finland. International Journal of Academic Research in Progressive Education and Development, 1(4), 34-46.

Copyright: @ 2012 The Author(s)

Published by Human Resource Management Academic Research Society (www.hrmars.com) This article is published under the Creative Commons Attribution (CC BY 4.0) license. Anyone may reproduce, distribute, translate and create derivative works of this article (for both commercial and non-commercial purposes), subject to full attribution to the original publication and authors. The full terms of this license may be seen at: http://creativecommons.org/licences/by/4.0/legalcode

\section{Vol. 1(4) 2012, Pg. 34 - 46}

Full Terms \& Conditions of access and use can be found at http://hrmars.com/index.php/pages/detail/publication-ethics 


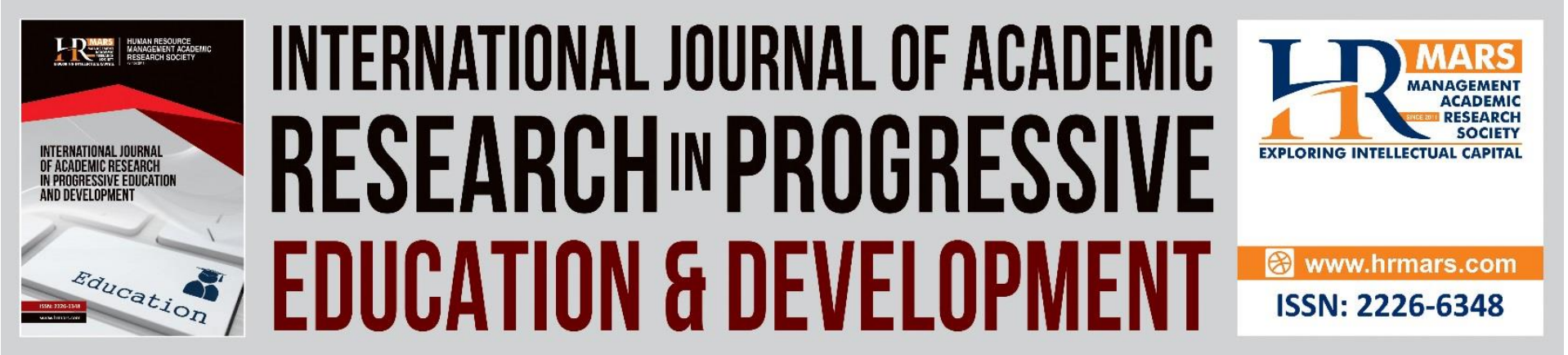

\title{
Parents' Perceptions of Multiprofessional Collaboration during Their Children's with Special Needs Transition to School in Finland
}

\author{
Katri Piippo-Naatanen \\ Lapland Hospital District, P.O. Box 8041, 96101 Rovaniemi, Finland \\ Email: katri.piippo-naatanen@lshp.fi \\ Satu Uusiautti \\ University of Lapland, P. O. Box 122, 96101 Rovaniemi, Finland \\ Email:satu@uusiautti.fi \\ Kaarina Maatta \\ University of Lapland, P. O. Box 122, 96101 Rovaniemi, Finland \\ Email: Kaarina.Maatta@ulapland.fi
}

\begin{abstract}
The transition from day care to the preschool and primary school presents several challenges for children, families, and professionals. Some child groups need special attention, for example, children with handicaps or special needs. What makes a successful transition must be clearly conceptualized from different viewpoints in order to discover workable transition strategies. The study focuses on Finnish parents' perceptions of the transition to school of their children with special needs. Furthermore, the parents' experiences and ideas of multiprofessional collaboration during the transition phase were dissected. The data were collected through role play method: parents of children with special needs were asked to continue the stories that covered the child's transition to school. Key dimensions that affect to the success of the transition phase are discussed as the results.
\end{abstract}

Keywords: Children with Special Needs, Inclusion, Multiprofessional Collaboration, Parents' Perceptions

\section{Introduction}

The time when children start school is a very special phase of life: becoming a school girl of school boy is a big step that may seem simultaneously frightening and exciting. In Finland, the period of pre-school education is a transition year to primary school for six-year-old children (Turunen, 2012) and nearly all go to preschool (96\% of the this age group) (Eyridice, 2009). All Finnish children have to go to school at the age of seven (Finnish Education Act, 628/1998) and there is very little stress placed on academics in a child's life before that (Kupiainen, Hautamaki and Karjalainen, 2009). 
For most children, school usually appears pleasant and learning new skills is something fascinating. However, the transition from day care to the preschool and primary school presents several challenges for children, families, and professionals. Kagan and Neuman (1998) use the definition of transition to refer to the continuity of experiences that children have between periods and between spheres of their lives. When starting school, children must enter a new setting that is very different from previous settings (Conn-Powers, RossAllen and Holburn, 1990) and, for example, children need to adapt new social roles (Entwisle, and Alexander, 1998). Children's school readiness may vary substantially (Magnuson et al., 2004; Magnuson and Waldfogel, 2005). Some child groups need special attention, for example, children from economically disadvantaged families (Magnuson et al. 2004) or children with handicaps or special needs (Kemp and Carter 2004). During this transition, early intervention is one of the most effective means of improving long-term social and academic outcomes in children with special needs (e.g., Fox et al., 2002; see also Forest et al., 2004). Care will be needed to ensure that hard-won preschool gains are not lost (Forest et al., 2004).

Ramey at al (1998) studied children's and parents' perceptions of children's school adjustment and attitudes toward school among American kindergartners and their primary care givers $(n=4,582)$. The most frequently mentioned type of problem reported by parents was in the social and behavioral category, for example difficulties in making friends or problems with anger management. The second frequently mentioned problem was related to children's disabilities, such as speech, language problems, ADHD, LD, or hearing problem while the third problem according to parents' assessment was the child's school readiness.

What makes a successful transition must be clearly conceptualized from different viewpoints in order to discover workable transition strategies. This is important when considering how long-lasting effects the transition will have in children's school careers. The study at hand draws attention to a little studied field (cf. Entwisle and Alexander, 1998). Namely, it focuses on Finnish parents' perceptions of the transition to school of their children with special needs. Parents' perceptions are important for many reasons: they are one of the key actors to enhance children's transition to school (Dockett and Perry, 2003), parental involvement is an important predictor of children's achievement in school, too (Englund et al., 2004)-and parents know their children the best. Furthermore, in this study, the parents' experiences and ideas of multiprofessional collaboration during the transition phase were dissected.

Multiprofessional collaboration is a key concept of this study. Family-professional partnerships make one of the key factors in the effectiveness of behavioral intervention efforts in children's transition to school (Fox et al, 2002). Multiprofessional collaboration and how to develop it is a challenge of the today's society: the goal is to preventatively support pupils in order to avoid unnecessary transitions to special education (Thomas and Vaughan, 2007). This involves the ability to detect problems in time and act appropriately. Multiprofessional collaboration also necessitates co-operation with parents.

Careful planning is, therefore, crucial (Conn-Powers, Ross-Allen and Holburn, 1990). Basically, children with special needs need personal evaluations where a pupil's own strengths and developmental needs are considered. The need for support may vary from temporary to continuous, from less to more intensive, and from one form of support to a combination of supportive methods. Problems in individual students' well-being increase the need for pupil 
welfare the most directly (Koskela, Maatta and Uusiautti, 2012). Estimations about the number of children who need support vary. According to STAKES (2008), about every third student has problems that require further examination or attention if also difficulties in communication and learning are taken into account. Behavioral and emotional problems have increased and problems are more serious than before (Webb et al., 2004).

Individual planning is an important part of Finnish early childhood education and educators and parents together draw up an individual plan for each child (National Curriculum Guidelines, 2004). Turunen (2012) has noted that individual plans can be a valuable tool in building continuity in the transition process and promote a positive transition experience. In all, providing all students with equal educational opportunities and removing obstacles to learning, especially among the least successful students, have been the leading principles in Finnish educational policy (Maatta and Uusiautti, 2012).

The forms of general and intensified support in Finnish basic education are differentiation, student counseling, pupil welfare, remedial education, part-time remedial education, aids, supervision of school going, and other guidance and support services. Special support is provided for pupils whose development, growth, and learning cannot be sufficiently secured with other forms of support. Special support will be provided either as a part of general or extended compulsory education as arranging flexible grouping, adjusting group sizes, concurrent teaching, team teaching, or as a part of club activity or morning and afternoon care. New statutory processes include pedagogical evaluations, curricula, pedagogical accounts, and decisions of special support and plans of arranging personal teaching. (Curriculum for pre-primary and primary education, 2011; Administrative Law 434/2003)

In this study, the success of transition from preschool to school was dissected through parents' perceptions. The purpose was to find the means that have been functional when children with special needs went to school. Additionally, the study focused on challenges and experiences of success faced during the transition phase and thus provide more information about the functional practices during the transition phase. The significance of multiprofessional collaboration was also discussed.

\section{Method}

This study focused on parents' perceptions of their children's transition to school. The following research questions were set for the study:

(1) What features support the success of transition to school in children with special needs according to parents' perceptions?

(2) What features hinder the success of transition to school in children with special needs according to parents' perceptions?

(3) What is required of the multiprofessional staff during the transition to school of children with special needs according to parents' perceptions?

The research questions were answered through obtaining data among parents who had children with special needs. The research participants form a very special group: the number of parents of children with special needs is limited in a small country like Finland. Furthermore, they are not very easily reachable or eager to bring out their experiences. Therefore, the data were collected through role play method: fictitious frame stories were 
composed and parents were asked to continue the stories (Eskola, 1997). The stories, thus, covered a topic that was familiar to the parents but they did not have to directly talk about their own child but their experiences and perceptions of the practical matters during the transition phase. The frame stories, designed to follow the research questions, were the following:

Frame story number 1: Brett is a pupil with special needs. Brett has just started the first grade. After two weeks, things at school have been going well. Brett goes to school happily. Write a short story that discusses what things/persons/events have influenced positively on Brett's transition from pre-school to school.

Frame story number 2: Brett is a pupil with special needs. Brett has just started the first grade. After two weeks, Brett would not like to go school and finds school distasteful. Write a short story that discusses what things/persons/events have influenced negatively on Brett's transition from pre-school to school.

Parents who participated in the study were recruited from the Finnish association of Relatives of Children with Special Needs (Erityislasten omaiset ry:n ELO). Altogether ten stories were obtained from parents in 2012. Parents wrote based on the frame story about the time their own children with special needs had started school. The data gathered by role play method is written data that can be analyzed with various methods: various themes can be found in the stories, a typical story can be composed based on the data, or the discourses in the stories are analyzed when the focus is on the way issues are discussed in the data. In the stories obtained, parents' experiences and perceptions were under investigation. It was considered a suitable method because the study of narrative is the study of the ways humans experience the world. A story is a way of characterizing the phenomena of human experience (Connelly and Clandinin, 1990) and storytelling seeks to better understand the "why" behind human action (Polkinghorne, 1995).

\section{Results}

Features that support the transition to school in children with special needs

Parents highlighted the importance of having the familiar professionals during the transition phase: it is important to have therapists who are already familiar to a child to support during this significant phase. Caring adults provide safe atmosphere. Likewise, teachers have a great role. The future teacher can familiarize with a child with special needs before the child starts school, for example, by visiting the child's preschool. Also the child can visit the school already beforehand. This way not only the child but also the teacher gets important information and becomes better prepared to the transition phase.

"The school personnel was familiar and the environment was completely safe. The prospective teacher of the special grade visited the preschool and met the new pupils regularly, about once a month." (3)

Although multiprofessional collaboration has a central role in supporting children with special needs, it does not guarantee the use and emergence of multiprofessional know how: good team work and interaction skills are needed as well as open and trustful atmosphere among the group members. In addition to these, parents emphasized shared understanding about 
the goals or those basic tasks that the collaboration aims at (see also Karila and Nummenmaa 2001).

Secondly, parents considered multiprofessional meetings salient as in these meetings, information about the child with special needs could be shared. Planning of arranging personal support usually starts already at preschool and should be continued at school as a part of the multiprofessional collaboration.

"Regular meetings to make plans of arranging personal support were held already at preschool and all parties participated and discussed issues thoroughly. It gave a feeling that the goals were clear and everyone would do their best." (3)

Parents who actively take care of their children's special needs have to do multiple tasks. They must inform the professionals of their children's development and participate in planning the special support their children need at preschool and at school. Parents in this study expected that professionals would provide them with support and means to cope with everyday life and clear guidelines what they can do at home to enhance their children's development (cf. Veijola, 2004).

"Time at preschool went nicely, the long relationship with the special needs assistant was safe. And even if we changed the preschool, the assistant remained the same. The future school was introduced already during preschool. The assisting teacher visited Brett and the assistant every now and then to guide and plan preschool teaching together with them and the special early childhood education teacher." (5)

It was considered beneficial if the assistant could assist the child when needed but simultaneously let the child learn to be self-directed when possible. Mostly, the parents highlighted the individuality of their children and how it could be noticed when enhancing their amusement, social relationships, and learning and development. The parents were especially concerned of how their children would integrate in the child group at school. For example, some children would need help in communication:

"They used sign language to support speech at school too which was important because speaking and communicating was especially challenging. New adults found it difficult to understand Brett at first and Brett was frustrated in these situations. Therefore, it is important to the child that the group includes some already familiar children who can communicate quite fluently with each other."(1)

People around children with special needs have to spend time with them to learn to know the children's typical reactions, points of interest, and habits (see also Launonen, 2009). Becoming familiar with the child's special way of communicating is crucial for the success of multiprofessional collaboration, too, and speech therapists', sign language instructors', interpreters' help is irreplaceable. Parents and teachers spend plenty of time with children and therefore, they need to have as much information as possible about the child and about the communication methods. 
Features that make the transition to school in children with special needs difficult Although the parents in this study wrote about the importance of the multiprofessional collaboration, it could also be considered negative. The quality of collaboration and interaction can be experienced negatively for example when a teacher does not have necessary skills and professional knowledge to work with children with special needs. This situation concerned parents in this study. Especially, the parents discussed the realization of personal plans and arrangements at school. The teacher is responsible for implementing the actions written in plans in practice. Likewise, the fulfillment of the plans should be regularly evaluated:

"All the forms and notes ought to be realized (personal plans). The teacher does not know how to support the child. Integration was not successful in lessons and the child was just standing by and had to work hard at home. Mother had to organize all the meetings and be active. Peer relationships were not paid attention at preschool. It would be important to recognize the child's strengths." (1)

Another issue that emerged from the data was negative changes in a child's condition. A child could, for example, start having more epileptic fits in the new surroundings causing parents worry and negative feelings. New medication and absenteeism from school make the transition more difficult. New people and unfamiliar surroundings, and the child's insecurity may increase the number and form of medical issues.

"The fall came and Brett started the path as a pupil. Everything was new: assistants, many hands instead of one familiar and safe assistant), environment, habits, and actions. At first, insecurity and even worry occupied parents' minds during school days. Soon Brett started to have new kinds of epileptic fits. A new medication was started but still, Brett kept having the fits. We did not dare to put Brett in school and the transition to school was quite irregular. It seemed that the thought of everything new was a bit too much to Brett, too." (5)

The child's health is important to parents and it cannot be always predicted how a different learning environment can affect the success of transition to school. The parents in this study thought of the possibility of changing the school environment already beforehand so that it would enhance the child's well-being.

"Brett is severely disabled who does not cope alone at all and needs adults' help in everything. Starting school meant meeting 11 new adults, 'learning to know their hands', adjusting to the new environment (colors, lights, smells, voices), and daily rhythm. Everything new, especially many new things coming in life at the same time, is tiring and increases the flood of sensations. Noise causes a lot of pain to a child who uses hearing aid." (6)

Thirdly, the parents were concerned about stigmatization. Children with special needs can be bullied at school in many ways; for example, not becoming invited to a classmate's birthday party can be seen as bullying. The parents noted that if the child's need for support diminishes, it is important give less support and rather focus on providing timely support. On the other hand, the parents in this study worried about their concern, too: they realized that their worrying was not to benefit their children. Children sense if parents or teachers are nervous. 
"What was negative was that Brett was somehow labeled although the need for special support had almost totally disappeared. Sometimes it feels like people keep on about something that is not relevant any longer. The multiprofessional support was important when topical but now it can be loosened."(8)

"Peer relationships were problematic. Brett was invited to a birthday party. Also the small village community could hinder the emergence of social relationships. The child was stigmatized as special because of the lack of communication abilities." (1)

\section{Parents' perceptions of multiprofessional collaboration}

The parents' in this study discussed the ways of utilizing multiprofessional collaboration during the transition phase from preschool to school. According to their perceptions, sometimes different issues are different to parents than to professionals. The parents highlighted smooth practices in the everyday life, such as school transportation and morning and afternoon care. When taken care of appropriately, they provide the sense of security in a child's school day and therefore can function as a salient positive factor in the transition.

Skilled multiprofessional staff has naturally a key role in successful transition, too. Reliable and permanent adults who stay with the child during the transition process make the basis for a good start. Agreements of common methods used at preschool and school increase the sense of security. In this study, the parents pointed out the meetings with the multiprofessional staff and personal plans for arranging special assistance. Interaction between the parties was especially important to parents when it comes to building trust.

The role that a child's assistant has was stressed by parents in this study (see also Maensivu, Uusiautti and Maatta, 2012). The special needs assistant is important to the smoothness of the child's everyday living. However, the assistant is the least educated when compared to early childhood education teachers and classroom teachers, and thus, not heard at the time of planning special support. Therefore, it seemed relevant to have other staff to take care of children's everyday life, too, to build trust between them and parents and to boost the sense of solidarity in taking care of children with special needs. In any case, the personnel need each other's expertise and researchers' efforts (see Launonen, 2009).

"It just feels so safe to have more people to support your child and they give valuable information already beforehand." (2)

According to the parents, multiprofessional collaboration must be developed so that various families and their individual characteristics are paid attention to but also to enable early intervention. Furthermore, a child with special needs should be evaluated in various environments as interaction can be learned and practiced in numerous situations. Negotiations skills, ability to admit mistakes and receive feedback were considered crucial to everyday life and how to make it as smooth as possible through the multiprofessional collaboration.

"Brett got used to the school rhythm relatively well. It was very important to wake up Brett's body before the school day started. Likewise, it was important to keep up the rhythm at home. To give food at certain hours and go to bed in good time." (4) 
The parents considered information about communication with children with severe disabilities salient. Although various professionals have some education about interaction and basics of communication, unfortunately their skills remain constricted compared, for example, to speech therapists' knowledge. Therefore, school personnel can find it difficult to work with people with severe disabilities. Moreover, the parents emphasized they also need to be supported when finding ways of communicating with their children.

\section{Discussion}

Parents' perceptions reported in the results section reveal how comprehensive and wideranging the need for special support is. The results also show that it is not just about the question of children's school readiness but the preparedness of the school, too. As the pursue is to offer children with special needs opportunities to study at their neighboring school supported by various measures, new challenges are faced to realize the principles of inclusion in practice.

The need for supplementary education among the multiprofessional team supporting children with special needs is obvious but, in addition to that, the municipal and local authorities have to be sufficiently informed. Commitment is crucial and concerns everyone in the multiprofessional group. Shared meetings should be planned so that the family can fully participate in making decisions on the child's special arrangements at school.

Parents' perceptions discussed in this study are in line with other studies on the issue, too. Next, we will point out here some key dimensions that affect to the success of the transition phase. Based on the results, they need to be considered especially carefully when pursuing enhancing the smoothness of the transition to school among children with special needs.

\section{Conclusion}

First, adequate planning of personal support was highlighted by parents in this study. "Although a growing literature attests to the importance of transition planning, a need exists to identify the full set of elements within a transition plan that are important for child success" (Forest et al., 2004, 104). Therefore, planning should be specifically focused on the transition, be based on preschool experiences and have the continuum to the future. According to Fox et al (2002), "the goal of transition planning is to mitigate the stress that may be incurred through the transition process by maximizing continuity of services and supports and minimizing interruptions in services and disruptions caused by changing services, locations, and personnel" (p.153). The idea is that positive behavior support could be implemented across all of the child's environments, is composed of a number of individualized strategies, and address the prevention of problems and the development of new skills and improved patterns of social interaction. For example, quality preschool or childcare predicts ease of adjustment, enhances pre-academic competencies, and strengthens social and selfregulatory skills (Rimm-Kaufman, Pianta and Cox, 2000).

Social skills make one of the key issues in transition. The significance of the child's peer relationships was highlighted in parents' stories. Likewise, Mclntyre, Blacher, and Baker (2006) discovered that fostering early social skills in children with special needs may be an important target for increasing the positive adaptation to school. Barbara Bowman (1994, 218) asserted that "It is essential for educators to understand the nature of the problems 
faced by children at risk of school failure and to design educational solutions that take into account the importance of the social context in which learning takes place." Indeed, in Dockett and Perry's (2003) study of what is important as students start school, children considered having friends at school the most important factor while parents and teachers emphasized adjustment: by adjustment, teachers meant ability to work in groups without relying on the teacher and parents meant children's ability to separate from them and fit in the group (see also Ladd \& Price, 1987). In all, adults described a child's transition to school as successful if the child expressed positive attitudes toward school (Dockett and Perry, 2003).

Finally, according to the parents' perceptions, it appears significant that the focus was rather on removing barriers to learning than fulfilling individual needs. Not enough attention is paid on how to conquer individual barriers to learning: the results suggest that systematic and specialized support regardless of the support method is required (see also Holopainen and Savolainen, 2008). Rule, Fiechtl, and Innocenti (1990) introduced already over two decades ago a survival skills curriculum aimed to children with handicaps starting school. The fundamental though was to provide children with skills that will help them to encounter different learning conditions as independently as possible, and basically, the idea was the same that parents in this study demanded: to provide support only when needed. That requires discernment of the teacher and other staff but also open communication about the child's progress.

Indeed, timely and considerate communication between the multiprofessional staff and parents is needed (see also Eriksson and Arnkill, 2005; Ramey and Ramey, 1994; 1998). Similarly, building trust between teachers and parents was found crucial. One the one hand, it is important that children with special needs and their parents learn to know the teachers. On the other hand, it is also important that teachers consider this collaboration as a natural part of their job. Rimm-Kaufman, Pianta, and Cox (2000) remind that teachers' judgments about problems in the classroom must be evaluated in relation to teachers' attributes, such as their ethnicity and skill level, that may influence their closeness and identification with their students. Teachers unfamiliar with teaching a class with children with special needs may need supplementary education. In addition, active developmental work through multiprofessional collaboration widens the teacher perspective.

Collaboration between the teacher and multiprofessional team should be an integral part of the education (Openshaw, 2008). For example, Morgan, Ashbaker, and Forbush (1998) claim that too little attention has been paid to developing the collaborative skills of the actual classroom team (see also Logan, 2006). Unquestionably, the help and support given to families and children with special needs by a fluent multiprofessional team cannot be undervalued (see also Takala, 2007). The ultimate aim is, anyway, to promote continuity in the lives of young children with special needs (McIntyre, Blacher and Baker, 2006) - to make transitions as smooth as possible.

\section{References}

Bowman, B. (1994). The challenge of diversity. Phi Delta Kappan, 76(3), 218-225.

Connelly, F. M., \& Clandinin, D. J. (1990). Stories of experience and narrative inquiry. Educational Researcher, 19(5), 2-14. 
Conn-Powers, M. C., Ross-Allen, J., \& Holburn, S. (1990). Transition of young children into the elementary education mainstream. Topics in Early Childhood Special Education, 9(4), 91-105.

Curriculum for Pre-primary and primary education. (2011). ROvaniemi, Finland: City of Rovaniemi.

Dockett, S., \& Perry, B. (2003). The transition to school: what's important. Educational Leadership, 60(7), 30-33.

Englund, M. M., Luckner, A. E., Whaley, G. J. L., \& Egeland, B. (2004). Children's achievement in early elementary school: longitudinal effects of parental involvement, expectations, and quality of assistance. Journal of Educational Psychology, 96(4), 723-730. DOI: 10.1037/0022-0663.96.4.723

Entwisle, D. R., \& Alexander, K. L. (1998). Facilitating the transition to first grade: the nature of transition and research on factors affecting it. The Elementary School Journal, 98(4), 351-364.

Eriksson, E., \& Arnkil, T.-E. (2005). Huoli puheeksi. Opas varhaisista dialogeista [Talk about your worries. A manual for early dialogues]. Jyvaskyla, Finland: Gummerus.

Eskola, J. (1997). Elaytymismenetelmaopas [Manual for using role play method]. Tampere, Finland: University of Tampere.

Eurydice. (2009). National summary sheets on education systems in Europe and ongoing reforms. Finland: European Commission.

Forest, E. J., Horner, R. H., Lewis-Palmer, T., \& Todd, A. W. (2004). Transitions for young children with autism from preschool to kindergarten. Journal of Positive Behavior Interventions, 6(2), 103-112.

Fox, L., Dunlap, G., \& Cushing, L. (2002). Early intervention, positive behavior support, and transition to school. Journal of Emotional and Behavioral Disorders, 10(3), 149-157.

Holopainen, L., \& Savolainen, H. (2008). Erityinen tuki - hyvinvoinnin esteiden tasoittaja [Special support - smoothing down the obstacles to well-being]. In K. Lappalainen, M. Kuittinen, \& M. Merilainen (Eds.), Pedagoginen hyvinvointi [Pedagogical well-being] (pp. 97-110). Turku, Finland: Painosalama.

Kagan, S. J., \& Neuman, M. J. (1998). Lessons from three decades of transition research. The Elementary School Journal, 98(4), 365-379.

Karila, K., \& Nummenmaa, A. (2001). Matkalla moniammatillisuuteen. Kuvauskohteena paivakoti [Toward multiprofessionalism. The case Day care center]. Juva, Finland: WS Bookwell.

Kemp, C., \& Carter, M. (2005). Identifying skills for promoting successful inclusion in kindergarten. Journal of Intellectual and Developmental Disability, 30(1), 31-44. doi: 10.1080/13668250500033110

Koskela, T., Maatta, K., \& Uusiautti, S. (2012). Pupil welfare in Finnish schools - communal or falling apart? Early Child Development and Care, iFirst. doi: 10.1080/03004430.2012.725049

Kupiainen, S., Hautamaki, J., \& Karjalainen, T. (2009). The Finnish education system and PISA. Helsinki: Ministry of Education. Retrieved from http://www.pisa2006.helsinki.fi/files/The_Finnish_education_system_and_PISA.pdf

Ladd, G. W., \& Price, J. M. (1987). Predicting children's social and school adjustment following the transition from preschool to kindergarten. Child Development, 58, 1168-1189. 
Launonen, K. (2009). Vuorovaikutus - kehitys, riskit ja tukeminen kuntoutuksen keinoin [Interaction - development, risks, and support with remediation]. Jyvaskyla, Finland: Gummerus.

Logan, A. (2006) The role of the special needs assistant supporting pupils with special educational needs in Irish mainstream primary schools. Support for Learning, 21(2), 9299.

Magnuson, K. A., Meyers, M. K., Ruhm, C. J., \& Waldfoge, J. (2004). Inequality in preschool education and school readiness. American Educational Research Journal, 41(1), 115157.

Magnuson, K. A., \& Waldfogel, J. (2005). Early childhood care and education: effects on ethnic and racial gaps in school readiness. The Future of Children, 15(1), 169-196. doi: 10.1353/foc.2005.0005

McIntyre, L. L., Blacher, J., \& Baker, B. L. The transition to school: adaptation in young children with and without intellectual disability. Journal of Intellectual Disability Research, 50(5), 349-361. doi: 10.1111/j.1365-2788.2006.00783.x

Morgan, J., Ashbaker, B., \& Forbush, D. (1998) Strengthening the teaching team: Teachers and paraprofessionals learning together. Support for Learning, 13(3), 115-117.

Maensivu, K., Uusiautti, S., \& Maatta, K. (2012). Special needs assistants - the special characteristic and strength of the school system of Finland. European Journal of Educational Research, 1(1), 23-36.

Maatta, K., \& Uusiautti, S. (2012). How do the Finnish family policy and early education system support the well-being, happiness, and success of families and children? Early Child Development and Care, 182(3-4), 291-298. doi: 10.1080/03004430.2011.646718

National Curriculum Guidelines on Early Childhood Education and Care in Finland. (2004). Helsinki: STAKES.

Openshaw, L. (2008). Social work in school. Principles and practice. New York, NY: The Guilford Press.

Polkinghorne, D. E. (1995). Narrative configuration in qualitative analysis. In J. A. Hatch \& R. Wisniewski (Eds.), Life history and narrative (pp. 5-24). London: Falmer Press.

Ramey, S. L., Lanzi L. G., Phillips, M. M., \& Ramey, C. T. (1998). Perspectives of former Head Start children and their parents on school and the transition to school. The Elementary School Journal, 98(4), 311-327.

Ramey, S. L., \& Ramey, C. T. (1994). The transition to school. Phi Delta Kappan, 76(3), 194199.

Ramey, S. L., \& Ramey, C. T. (1998). The transition to school: Opportunities and challenges for children, families, educators, and communities. The Elementary School Journal, 98(4), 293-295.

Rimm-Kaufman, S. E., Pianta, R. C., \& Cox, M. J. (2000). Teachers' judgments of problems in the transition to kindergarten. Early Childhood Research Quarterly, 15(2), 147-166.

Rule, S., Fiechtl, F. J., \& Innocenti, M. S. (1990). Preparation for transition to mainstreamed post-preschool environments: development of a survival skills curriculum. Topics in Early Childhood Special Education, 9(4), 78-90.

STAKES. (2008). Erityisopetukseen siirretyt peruskoulun oppilaat laaneittain ja kunnittain syksylla 2007 [Comprehensive school pupils who were transformed in special education by provinces and municipalities in the fall 2007]. Retrieved from http://www.stat.fi/erop/2007/ erop_2007_2008-06-10_tau_007.html 
Takala, M. (2007). The work of classroom assistants in special and mainstream education in Finland. British Journal of Special Education, 34(1), 50-57.

Thomas, G., \& Vaughan, M. (2007). Inclusive education. Readings and reflections. Glasgow: Bell \& Bain Ltd.

Turunen, T. (2012). Individual plans for children in transition to pre-school: a case study in one Finnish day-care centre. Early Child Development and Care, 182(3-4), 315-328. doi: 10.1080/03004430.2011.646728

Veijola, A. (2004). Matkalla moniammatilliseen perhetyöhön - lasten kuntoutuksen kehittaminen toimintatutkimuksen avulla [On a way toward multiprofessional family work - developing children's rehabilitation through action research] (Doctoral thesis, University of Oulu, Oulu, Finland).

Webb, R., Vuillamy, G., Hamalainen, S., Sarja, A., Kimonen, E., \& Nevalainen, R. (2004). Pressures, rewards and teacher retention: A comparative study of primary teaching in England and Finland. Scandinavian Journal of Educational Research, 48(2), 169-188. 